\title{
HUBUNGAN ANTARA EQUALITY BEFORE THE LAW DALAM PENEGAKAN HUKUM DI INDONESIA DENGAN HARMONISASI KONFLIK ANTAR LEMBAGA PENEGAK HUKUM
}

\author{
Dadin E. Saputra ${ }^{1}$ \\ Fakultas Syariah dan Ekonomi Islam, JL. A. Yani Km, 4,5 Banjarmasin \\ e-mail:delawfirm30@gmail.com
}

\begin{abstract}
This paper aims to analyze the relationship between the application of the legal principle of equality before the law in law enforcement in Indonesia with the harmonization of conflict between the state institutions and the National Police Commission. The method used in this research is normative juridical, namely research in the review by reference and based on the norms and rules of law, the legislation in force, theories and doctrines of law, jurisprudence, and materials other literature relevant to the research topic. From the analysis of the data, it can be concluded that there is a recognition of the principle of normative and empirical rule of law, namely that all the issues are resolved with the law as the supreme guidance. Normatively either in the Constitution of the Republic of Indonesia Year 1945, and in Undang-Undang Nomor 39 Tahun 1999 on Human Rights, the principle of equality of treatment before the law has been published in a comprehensive manner, as the rights that must be respected, guaranteed, protected and met by the state. Disharmony between institutions or law enforcement agency that is now emerging, should be immediately solved by basing the legislation that exists.
\end{abstract}

\begin{abstract}
Abstrak : Paper ini bertujuan untuk menganalisis tentang hubungan antara penerapan hukum asas equality before the law didalam penegakan hukum di Indonesia dengan harmonisasi konflik antar lembaga Negara yakni Polri dan KPK. Metode penelitian yang digunakan dalam penelitian ini adalah yuridis normatif, yaitu penelitian yang dalam pengkajiannya dengan mengacu dan mendasarkan pada normanorma dan kaidah-kaidah hukum, peraturan perundang-undangan yang berlaku, teori-teori dan doktrin hukum, yurisprudensi, dan bahan-bahan kepustakaan lainnya yang relevan dengan topik penelitian. Dari hasil analisis data, dapat disimpulkan bahwa terdapat pengakuan normatif dan empirik akan prinsip supremasi hukum, yaitu bahwa semua masalah diselesaikan dengan hukum sebagai pedoman tertinggi. Secara normatif baik dalam Undang-Undang Dasar Negara Republik Indonesia Tahun 1945, maupun dalam Undang-Undang Nomor 39 Tahun 1999 Tentang Hak Asasi Manusia, prinsip equality treatment before the law telah dimuat secara komprehensif, sebagai hak asasi yang harus dihormati, dijamin, dilindungi dan dipenuhi oleh negara. Disharmonisasi antar lembaga atau institusi penegak hukum yang sekarang sedang marak terjadi, seharusnya dapat segera diselesaikan dengan mendasarkan kepada peraturan perundang-undangan yang ada.
\end{abstract}

Kata Kunci : Equality Before The Law, Penegakan Hukum, dan Harmonisasi Konflik. Antar Lembaga Penegak Hukum

\section{Pendahuluan}

Negara hukum sebagai suatu istilah dalam perbendaharaan bahasa Indonesia merupakan terjemahan dari rechtsstaat maupun rule of law. Ketiga istilah tersebut memiliki arah yang sama, yaitu mencegah kekuasaan absolut demi pengakuan dan

1 Dosen Non PNS Fakultas Syariah Dan Ekonomi Islam IAIN Antasari Banjarmasin Kalimantan Selatan dan Praktisi Hukum (Advokat PERADI) perlindungan hak asasi. ${ }^{2}$ Dalam Kamus Bahasa Indonesia, istilah negara hukum diartikan sebagai:

"Negara yang menjadikan bukum sebagai kekuasaan tertinggi. ${ }^{3}$ Lebih lanjut dijelaskan bahwa negara bukum

2 Azhary, Negara Hukum Indonesia-Analisis Yuridis Normatif Tentang Unsur-unsurnya, Cet. Pertama (Jakarta : UI Press, 1995), hal. 30. Pernyataan yang sama dapat dijumpai pada hlm. 33.

3 Pusat Pembinaan dan Pengembangan Bahasa, Kamus Besar Bahasa Indonesia, Edisi Kedua, Cet. Kedelapan (Jakarta : Balai Pustaka, 1996), hlm. 685. 
terdiri dari negara bukum formal dan negara bukum material. Negara bukum formal adalah negara yang segala tindakannya didasarkan hanya atas bukum yang tertulis, yang secara formal tercantum dalam peraturan perundang-undangan, sedangkan negara bukum material adalah negara yang tidak hanya mendasarkan segala tindakannya pada peraturan perundang-undangan, tetapi juga menyelenggarakan kesejabteraan umum. "."

Gagasan negara hukum yang didasarkan atas prinsip-prinsip demokrasi dan keadilan sosial dalam masyarakat bangsa Indonesia yang bersatu merupakan suatu gagasan yang nampaknya didasarkan atas persepsi dari para pendiri negara Republik Indonesia terhadap kenyataan sejarah yang pernah dialami bangsa Indonesia. Dalam telaah Mohammad Tahhir Azhary tentang ciri-ciri negara hukum yang ideal dirumuskan 9 (sembilan) ciri yaitu : (1) kekuasaan sebagai amanah; (2) musyawarah; (3) keadilan; (4) persamaan; (5) Hak Asasi Manusia; (6) peradilan yang bebas dan mandiri; (7) perdamaian; (8) kesejahteraan dan (9) tanggung jawab dan ketaatan rakyat. ${ }^{5}$

Azhary Alam dalam telaahnya juga merumuskan unsur-unsur negara hukum meliputi, (1) hukum bersumber pada Pancasila, (2) kedaulatan rakyat, (3) pemerintahan berdasar atas sistem konstitusi, (4) persamaan kedudukan dalam hukum dan pemerintahan, (5) kekuasaan kehakiman yang bebas dari kekuasaan lainnya, (6) pembentuk undang-undang adalah Presiden bersama-sama DPR dan (7) sistem MPR. ${ }^{6}$ Menurut Sri Soemantri, negara hukum secara umum/ universal memiliki 4 (empat) yaitu : (1) pemerintah dalam melaksanakan tugas dan kewajibannya harus berdasar hukum atau peraturan perundang-undangan; (2) adanya jaminan terhadap hak-hak asasi manusia; (3) adanya pembagian kekuasaan dalam negara; (4) adanya pengawasan dari badan-badan peradilan (rechtterlijke controle). ${ }^{7}$

Pemikiran tentang negara hukum yang berkembang sebagaimana diuraikan di atas tidak lepas dari kondisi perkembangan sosial yang dapat ditelaah dalam dinamika ketatanegaraan yang ada.

\footnotetext{
Ibid.

Ibid.

Azhary, OpCit, hlm. 144.

Sri Soemantri Martisoewignjo, Asas Negara Hukum dan Perwujudannya dalam Sistem Hukum Nasional, dalam M.B. Muqoddas dkk, Politik Pembangunan Hukum Nasional, (Yogyakarta : UII Press, 1992), hlm. 28.
}

Demikian pula dengan ketatanegaraan Indonesia yang berkembang terus dan terakhir dengan diubahnya UUD 1945, sehingga akan berpengaruh terhadap berkembangnya pemikiran negara hukum sebagaimana yang dikembangkan oleh beberapa pakar hukum tata negara seperti Prof. Jimly Ashidiqqie yang mengembangkan prinsip-prinsip negara hukum menjadi 12. Kedua belas prinsip negara hukum menurut Prof. Jimly adalah : (1) supremasi hukum (supremacy of law); (2) persamaan dalam hukum (equality before the law); (3) asas legalitas (due process the law); (4) pembatasan kekuasaan; (5) organ-organ eksekutif independen; (6) peradilan bebas dan tidak memihak; (7) peradilan tata usaha negara; (8) peradilan tata negara; (9) perlindungan hak asasi manusia; (10) bersifat demokratis (democratische rechtsstaat); (11) berfungsi sebagai sarana mewujudkan tujuan bernegara (welfare rechtsstaat); dan (12) transparansi dan kontrol sosial.

Dengan memperhatikan unsur-unsur atau prinsip-prinsip negara hukum tersebut, maka dapat ditarik benang merah bahwa dalam negara hukum, hukum mempunyai kedudukan yang kuat, dan proses penyelesaian konflik tersebut dilakukan melalui mekanisme hukum, sehingga tetap terjamin hak asasi manusia dengan memberikan seluasluasnya masyarakat melakukan kontrol baik politik, sosial, dan hukum.

Pemaknaan "kontrol normatif " adalah suatu mekanisme penyelarasan norma hukum oleh lembaga negara karena adanya usulan atau desakan masyarakat terhadap berbagai produk hukum yang dihasilkan oleh lembaga negara yang diberikan kewenangan oleh konstitusi untuk melaksanakan tugas sehingga antar norma hukum yang dihasilkan atau yang ditetapkan memiliki nilai saling menjelaskan atau saling menjabarkan secara hierarkis. Secara sepintas unsur-unsur atau prinsipprinsip negara hukum yang dikemukakan di atas terdapat kesan adanya kekakuan dalam penyelenggaraan negara, sehingga terjadi pembatasan secara limitatif terhadap para penyelenggara negara.

Sebenarnya hal tersebut tidak demikian karena semua mekanisme penyelenggaraan negara diatur secara limitatif agar satu lembaga kekuasaan negara lainnya dapat berjalan sesuai dengan tugas, fungsi dan wewenang yang diberikan oleh konstitusi dan/ atau oleh undang-undang. Oleh karena itu, harus dibuka lajur-lajur normatif yang memungkinkan antara lembaga kekuasaan negara tersebut dapat menjalankan tugas, fungsi dan wewenangnya 
sebagaimana mestinya. Walaupun demikian, dalam negara hukum tidak dibenarkan mematikan demokrasi yang terwujud partisipasi masyarakat dalam pengelolaan negara, tetapi justru sebaliknya masyarakat diberikan saluran untuk mengekspresikan berbagai potensi, hak dan kewajibannya baik secara individual maupun kolektif dengan mekanisme yang diatur oleh hukum. Dalam pengertian ini, maka agar peraturan-peraturan yang diterbitkan tidak menyimpang atau bertentangan dengan norma-norma lainnya secara hierarkis, maka perlu diberikan hak tertentu kepada masyarakat baik secara individual maupun kolektif untuk mengontrol norma-norma tersebut melalui saluran hukum. ${ }^{8}$

Konsekuensi dari sistem negara hukum adalah adanya persamaan kedudukan baik dihadapan hukum maupun pemerintahan atau yang dikenal dengan istilah equality before the law sebagai salah satu elemen dalam penegakan hukum (law enforcement) di Indonesia. Prinsip persamaan sesungguhnya merupakan kelanjutan dari ide hak asasi manusia yang diilhami oleh tema normatif Revolusi Perancis, baik yang disebut generasi pertama yang merupakan hak-hak sosial politik (liberte), generasi kedua hak-hak ekonomi, sosial dan budaya (egalite) dan generasi ketiga yang disebut hak-hak solidaritas (fraternite). Hak-hak asasi yang terinspirasi oleh filosofi politik individualisme liberal dan doktrin ekonomi laissez faire, dirumuskan dengan istilah yang bersifat negatif berupa "kebebasan dari" intervensi negara dan yang membatasi kekuasaan negara."

Persamaan kedudukan bagi setiap warga negara dihadapan hukum maupun pemerintahan diharapkan mampu memberikan perlindungan hukum baik kepada masyarakat ataupun kepada lembaga atau institusi penegak hukum itu sendiri. Pembicaraan tentang realitas penegakan hukum dalam kaitan dengan prinsip equality before the law, lebih banyak dikedepankan dalam praktek peradilan pidana.

8 Bagir Manan, Kekuasaan Kehakiman di Indonesia Sejak Kembali ke UUD 1945, dalam Sri Soemantri Martosoewignjo dan Bintan R. Saragih, Ketatanegaraan Indonesia Dalam Kebidupan Politik Indonesia - 30 Tahun Kembali ke Undang-Undang Dasar 1945, (Jakarta : Pustaka Sinar Harapan, 1993), hlm. 273.

9 Burns H. Weston, Hak-Hak Manusia, dalam Hak-Hak Asasi Manusia dalam Masyarakat Dunia, Isu dan Tindakan, T. Mulya Lubis (Penyunting, diterjemahkan oleh A. Setiawan Abadi, Yayasan Obor Indonesia 1993, hlm. 12.
Di Indonesia, secara lebih khusus lagi dapat kita lihat dalam praktek penanganan perkara korupsi yang saat ini dilakukan secara intensif. Hal ini secara nyata dirasakan dan tampak dalam bentuk perampasan kemerdekaan dan perampasan harta benda sebagai bagian dari upaya paksa yang dilakukan dalam proses peradilan, apalagi jikalau perlakuan yang berbeda yang menimbulkan inequality before the law tadi yang menyangkut mereka yang memiliki kekuasaan atau pengaruh politik dan kemasyarakatan, maka hal itu akan tampak lebih menyolok lagi. Terkadang memang keadaannya menjadi lebih rumit, jikalau perlakuan yang tidak sama tersebut berkait dengan pertarungan politik, dalam arti penegakan hukum yang dilakukan diperhitungkan dengan pencitraan pemegang kekuasaan apalagi menggunakan kebesaran martabat sebuah institusi penegak hukum yang seharusnya dapat memberikan sebuah contoh bagi masyarakat dalam penegakan hukum di Indonesia tetapi justru memunculkan asumsi publik yang lebih mengarah kepada rasa pesimis dan berkurangnya kepercayaan terhadap penegakan hukum itu sendiri.

Pemberitaan nasional saat ini baik di media massa maupun media elektronik sedang gencargencarnya memberitakan tentang dua lembaga atau institusi penegak hukum terbesar di Indonesia, yaitu antara Kepolisian Negara Republik Indonesia yang kemudian disingkat dengan Polri dan Komisi Pemberantasan Korupsi yang kemudian disingkat dengan KPK, memanasnya dua lembaga atau insitusi penegak hukum pada akhir-akhir ini dimunculkan dari adanya asumsi-asumsi atau opini publik yang mulai menggeser nilai-nilai penegakan hukum kepada isu-isu politik. Dimulai dari penetapan tersangka salah satu petinggi Polri yang diusulkan oleh Presiden menjadi calon tunggal Kapolri yaitu Komisaris Jenderal BG (nama inisial atau alias) hingga dari penangkapan dan penetapan tersangka BW (nama inisial atau alias) salah satu pimpinan KPK. Keadaan ini banyak ataupun sedikit sangatlah mempengaruhi sistem ketatanegaraan sekaligus sistem hukum yang berkaitan dengan penegakan hukum (law enforcement) di Indonesia, karena dua lembaga yang saat ini sedang berseteru adalah sama-sama lembaga negara atau institusi penegak hukum yang seharusnya sama-sama saling bekerjasama sehingga memunculkan situasi yang dapat membangun sebuah harmonisasi antar lembaga negara atau institusi penegak hukum di Indonesia. 
Peneliti sendiri sepakat jika permasalahan yang terjadi saat ini seharusnya bukanlah antar lembaga negara atau institusi penegak hukum, mengingat yang tersangkut masalah hukum itu adalah person atau personal pejabat di Polri maupun KPK. Untuk itu, penegakan hukum di Indonesia harus dapat ditegakkan setegak-tegaknya dengan menerapkan secara konsisten asas equality before the law. Sehingga, bukan hanya dari segi legalitas (due process of law) saja, tetapi lebih dari itu yaitu hakekat hukum itu sendiri yaitu keadilan akan dapat dicapai, terlebih lagi demi menyelamatkan martabat lembaga negara atau institusi penegak hukum serta keutuhan dan keamanan negara kesatuan Republik Indonesia.

\section{Rumusan Masalah}

Dari uraian di atas maka penelitian ini merumuskan permasalahan yang akan di bahas yaitu, bagaimana penerapan hukum asas equality before the law didalam penegakan hukum di Indonesia dan sejauhmana hal tersebut membawa dampak sosial, politik, maupun hukum dalam harmonisasi konflik antar lembaga negara?

\section{Tujuan Penelitian}

Penelitian ini bertujuan untuk menganalisis tentang hubungan antara penerapan hukum asas equality before the law didalam penegakan hukum di Indonesia dengan harmonisasi konflik antar lembaga negara.

\section{Metode Penelitian}

Metode penelitian yang digunakan dalam penelitian ini adalah yuridis normatif, yaitu penelitian yang dalam pengkajiannya dengan mengacu dan mendasarkan pada norma-norma dan kaidah-kaidah hukum, peraturan perundangundangan yang berlaku, teori-teori dan doktrin hukum, yurisprudensi, dan bahan-bahan kepustakaan lainnya yang relevan dengan topik penelitian.

Pengumpulan bahan hukum dilakukan dengan studi pustaka yakni melalui pengkajian terhadap Undang-Undang Dasar 1945, Undang-Undang No. 48 Tahun 2009 Tentang Kekuasaan Kehakiman, Undang-Undang No.30 Tahun 2002 Tentang Komisi Pemberantasan Tindak Pidana Korupsi, Undang-Undang No.2 Tahun 2002 Tentang Kepolisian Negara Republik Indonesia, UndangUndang No.31 Tahun 1999 Jo. Undang-Undang No.20 Tahun 2001 Tentang Pemberantasan Tindak
Pidana Korupsi, Undang-Undang No.39 Tahun 1999 Tentang Hak Asasi Manusia, Undang-Undang No.18 Tahun 2003 Tentang Advokat, UndangUndang No.8 Tahun 1981 Tentang Hukum Acara Pidana, Kitab Undang-Undang Hukum Pidana, serta berbagai pustaka yang relevan dengan objek penelitian.

Pendekatan yang digunakan dalam penelitian ini adalah pendekatan yuridis, yakni menganalisis permasalahan tentang hubungan antara penerapan hukum asas equality before the law didalam penegakan hukum di Indonesia dengan harmonisasi konflik antar lembaga negara.

\section{Equality Before The Law}

Negara hukum (Rechtsstaat atan The Rule of Law) adalah konsep negara yang diidealkan oleh para pendiri bangsa yang membahas dan merumuskan UUD 1945 yang semula rumusan negara hukum tidak secara eksplisit disebutkan dalam UUD 1945, tetapi dijelaskan dalam Penjelasan UUD 1945. Walaupun penegasan negara hukum Indonesia, yakni negara berdasar atas hukum diletakkan pada Penjelasan UUD 1945, tidak mengurangi makna paham negara hukum karena Penjelasan merupakan bagian integral dari suatu Undang-Undang. ${ }^{10}$ Namun demikian, setelah perubahan UUD 1945 pengaturan prinsip negara hukum dituangkan dengan jelas dalam Pasal 1 ayat (3) UUD 1945 yang menyatakan bahwa "Negara Indonesia adalah Negara Hukum".

Konsepsi negara hukum tentu saja memberikan penegasan tentang penegakkan hukum di Indonesia, di mana telah diatur di dalam UUD 1945 yaitu Pasal 27 ayat (1) yang menegaskan bahwa "Segala warga negara bersamaan kedudukannya di dalam bukum dan pemerintahan dan wajib menjunjung bukum dan pemerintahan itu dengan tidak ada kecualinya" dan Pasal 28D ayat (1) yang menegaskan bahwa "Setiap orang berbak atas pengakuan, jaminan, perlindungan, dan kepastian bukum yang adil serta perlakuan yang sama dibadapan bukum”.

\footnotetext{
${ }^{10}$ Yusril Ihza Mahendra, Dekrit Presiden 5 Juli 1959 dan Implikasinya terbadap Perumusan Politik. Hukum Nasional, makalah disampaikan pada seminar sehari Menyongsong Hari Kemerdekaan RI ke 50, tanggal 5 Agustus 1945 yang diselenggarakan oleh ICMI Korwil DKI Jakarta, hlm. 21 .
} 
Prinsip persamaan atau equality yang biasanya diartikan yang sama harus diperlakukan sama, dan yang berbeda harus diperlakukan berbeda atau tidak sama, merupakan keadaan yang selalu ada dalam satu perbandingan (comparative). Equality juga diartikan sebagai uniformitas, yang merupakan proposisi dalam hukum dan moral bahwa orang yang sama harus diperlakukan sama, dan secara korelatif orang yang tidak sama harus diperlakukan secara berbeda. Dengan demikian pernyataan bahwa alasan seseorang diperlakukan dengan satu cara tertentu adalah karena dia "setara atau sama" atau "mirip atau identike" dengan orang lain yang menerima perlakuan seperti itu.

"Equality thus includes all statements to the effect that the reason one person should be treated in a certain way is that he is "like" or "equal to" or "similar to" oridentical to" or "the same as" another who receices such treatment."

Prinsip equality before the law ini sesungguhnya merupakan salah satu tema hukum yang tumbuh secara tidak terpisahkan dari konsepsi negara demokrasi, yang muncul seiring dengan runtuhnya feodalisme di Eropa Barat. Dengan tumbuhnya kapitalisme dan semakin besarnya kebebasan individu untuk melakukan perdagangan dalam pasar bebas yang disertai kebebasan secara politik dengan menguatnya parlemen atau rakyat dalam hubungan dengan raja, perubahan suasana telah mengakibatkan semakin menguatnya liberalisme. Tema hukum lainnya dalam konsepsi demokrasi adalah hak-hak individu, pengawasan rakyat atas pemerintahan, dan rule of law. ${ }^{12}$

Konsep ini merupakan salah satu unsur atau komponen dari apa yang dikatakan negara hukum (Rule of Law) yang demokratis yaitu supremacy of law, equality before the law dan due process of law. Rule of Law dengan unsur yang disebut diatas yang sekaligus sebagai makna yang membentuk prinsip fundamental konstitusi, dapat dilihat dari sudut pandang masing-masing unsur tersebut. Supremasi hukum merupakan prinsip bahwa hukum negara berada di atas kekuasaan dan preogratif penguasa yang sewenang-wenang. Prinsip kesetaraan didepan

11 Peter Westen, The Empty Idea Of Equality, 95 Harvard Law Review 537, hlm. 1.

${ }^{12}$ W. Friedman, Teori Dan Filsafat Hukum, Hukum dan Masalah-Masalah Kontemporer, diterjemahkan dari Legal Theory, oleh Muhammad Arifin, Penerbit PT. Raja Grafindo, 1994, hlm. 45-46. hukum diartikan sebagai ketundukan secara setara semua kelompok masyarakat kepada negara hukum negara yang dijalankan secara umum, dengan meniadakan pengecualian dan kekebalan pejabat pemerintahan dan penguasa atau orang-orang lain tertentu dari kewajiban untuk patuh kepada hukum yang berlaku. ${ }^{13}$

Prinsip ini menekankan adanya persamaan kedudukan setiap orang dalam hukum dan pemerintahan yang diakui secara normatif dan dilakukan secara empirik. Prinsip ini dalam perkembangannya kemudian, terutama dalam instrumen-instrumen hak asasi manusia dalam sejarah sejak Magna Charter sampai kepada Universal Declaration of Human Rights dan International Covenant On Civil and Political Rights dan diadopsi dalam Undang-Undang No.39 Tahun 1999, dan kemudian diangkat menjadi norma konstitusi dalam UUD 1945, dipahami sebagai larangan atas sikap dan tindakan yang diskriminatif dalam segala bentuk dan manifestasinya. Meskipun demikian prinsip persamaan didepan hukum masih dapat dibedakan secara jelas, karena pengertian equality before the law dipahami juga dalam kerangka due process the law sebagai prinsip yang mensyaratkan bahwa semua tindakan negara dilakukan melalui proses yang tertib dan teratur.

Due process the law meliputi procedural due process yang menekankan pada metode atau prosedur pelaksanaan kebijakan pemerintahan, yang harus menjamin kejujuran (fairness). Misalnya dalam suatu perkara yang sedang diperiksa pengadilan, para pihak harus sama-sama diberitahu dengan sepatutnya, dan memberi kesempatan yang sama pada para pihak untuk didengar dalam persidangan yang tidak berpihak. Substansive due process, merupakan jenis kedua yang substansif menyangkut kewajaran (reasonableness) isi kebijakan. Satu kebijakan yang dapat dianggap tidak memenuhi due process yang substansif jikalau secara rasional tidak berkaitan dengan tujuan legislasi yang sah atau jikalau kebijakan itu kabur secara tidak sah. ${ }^{14}$ Sementara itu satu prinsip umum lain yang dapat dikatakan merupakan bagian dari

13 A. V. Dicey, Introduction To The Study Of The Law Of The Constitution, Pengantar Studi Hukum Konstitusi, diterjemahkan Nurhadi M.A., Penerbit Nusa Media, 2007, hlm. 266.

${ }^{14}$ Ralph C. Chandler et. al., The Constitutional Law Dictionary, Volume 2, ABC-CLIO, Santa Barbara, California, Oxford England, 1987, hlm. 595. 
konsep equality before the law, ialah apa yang disebut egalite des arms (equality of arms), yang merupakan persamaan para pihak dalam proses peradilan, dimana litigasi akan ditata sedemikian rupa sehingga akan menjamin bahwa tidak satu pihak pun yang dapat menikmati keuntungan yang tidak sewajarnya dalam proses yang berlangsung (neither party enjoys an improper advantage). ${ }^{15}$

\section{Penegakan Hukum Di Indonesia}

Secara konsepsional, arti penegakan hukum terletak pada kegiatan menyerasikan hubungan nilai-nilai yang terjabarkan di dalam kaidah-kaidah yang mantap dan mengejawantah serta sikap tindak sebagai rangkaian penjabaran nilai tahap akhir untuk menciptakan, memelihara, dan mempertahankan kedamaian pergaulan hidup. ${ }^{16}$ Untuk menjawab "apa yang ditegakean", Soerjono lebih lanjut menegaskan bahwa dalam penegakkan hukum akan berkaitan dengan tiga hal penting yakni nilai, kaidah, dan pola perilaku. Nilai merupakan pandangan mengenai apa yang baik dan apa yang buruk dan bersifat abstrak. Selanjutnya dikonstruksikan dalam bentuk lebih konkret pada lingkup kaidah yang berisikan suruhan, larangan, atau kebolehan yang selanjutnya kaidah menjadi patokan bagi perilaku atau sikap yang pantas atau seharusnya. ${ }^{17}$

Ketiga hal tersebut merupakan tri-tunggal yang memiliki keterkaitan dan saling mempengaruhi dalam kehidupan masyarakat, sebab apabila terjadi ketidakserasian di antaranya dapat menimbulkan gangguan terhadap kerahasiaan dan kedamaian pergaulan hidup. Oleh karena itu, penegakkan hukum bukanlah semata-mata diartikan sebagai upaya mewujudkan kaidah yang terkandung dalam undang-undang atau diartikan hanya sebagai pelaksanaan keputusan-keputusan hakim yang kurang atau tidak mengindahkan nilai, kaidah, dan pola perilaku masyarakat, tetapi penegakan hukum terletak pada faktor-faktor yang mungkin mempengaruhinya dan bersifat netral.

\footnotetext{
${ }^{15}$ J. G. Merrills, The Development of International Law By The European Court of Human Rights, Manchester University Press, 1993, hlm. 185.

${ }^{16}$ Soerjono Soekanto, Faktor-faktor Yang Mempengarubi Penegakkan Hukum, Cet. Pertama (Jakarta : CV. Rajawali, 1983). hlm. 2.

${ }^{17}$ Ibid, hlm. 3.
}

Adapun faktor-faktor penegakan hukum meliputi :

1. Faktor hukumnya sendiri;

2. Faktor penegakan hukum, yakni pihak-pihak yang memberikan dan menetapkan hukum;

3. Faktor sarana atau fasilitas yang mendukung penegakan hukum;

4. Faktor masyarakat, yakni lingkungan dimana hukum tersebut berlaku atau diterapkan;

5. Faktor kebudayaan, yakni sebagai hasil karya, cipta, dan karsa yang didasarkan pada karsa manusia di dalam pergaulan. ${ }^{18}$

Pembicaraan tentang realitas penegakan hukum dalam kaitan dengan prinsip equality before the law, lebih banyak dikedepankan dalam praktek peradilan pidana. Di Indonesia, secara lebih khusus lagi dapat kita lihat dalam praktek penanganan perkara korupsi yang saat ini dilakukan secara intensif. Hal tersebut boleh jadi karena pembedaan perlakuan dalam keadaan yang sama, yang menimbulkan ketidakadilan tersebut sangat dirasakan baik oleh pihak yang menganggap dirinya korban maupun masyarakat pada umumnya. Hal itu secara nyata dirasakan dan tampak dalam bentuk perampasan kemerdekaan dan perampasan harta benda sebagai bagian dari upaya paksa yang dilakukan dalam proses peradilan pidana.

Jika dalam keadaan yang sama ternyata ada orang lain juga melakukan perbuatan yang diduga sama tetapi mendapat perlakuan yang berbeda dalam arti tidak mengalami tindakan hukum yang sama, rasa keadilan individu maupun rasa keadilan masyarakat secara terbuka diciderai dengan perlakuan yang tidak sama demikian. Keadaan ini menjadi lebih terbuka lagi karena faktor kebebasan pers, yang mampu secara luas meliput hal-hal demikian untuk diberitakan. Apalagi jikalau perlakuan yang berbeda yang menimbulkan inequality before the law tadi menyangkut mereka yang memiliki kekuasaan atau pengaruh politik dan kemasyarakatan, maka hal itu akan menjadi lebih mencolok lagi.

${ }^{18}$ Ibid, hlm. 5. Lihat Satjipto Rahardjo, Op. Cit,. hal. 23, yang menjelaskan bahwa unsur penegakkan hukum dibagi dalam dua golongan besar, yaitu unsur-unsur yang mempunyai tingkat keterlibatan yang agak jauh dan yang dekat. Unsur yang keterlibatannya dekat adalah Badan Legislaif (unsur pembuatan undang-undang), sedangkan tingkat keterlibatannya agak jauh adalah unsur lingkungan. 
Jika dikaji dan ditelaah secara mendalam, setidaknya terdapat tujuh faktor penghambat penegakan hukum di Indonesia ${ }^{19}$, ketujuh faktor tersebut ialah :

1. Lemahnya political will dan political action para pemimpin negara ini, untuk menjadi hukum sebagai panglima dalam penyelenggaraan pemerintahan. Dengan kata lain supremasi hukum masih sebatas retorika dan jargon politik yang didengung-dengungkan pada saat kampanye;

2. Peraturan perundang-undangan yang ada saat ini masih lebih merefleksikan kepentingan politik penguasa ketimbang kepentingan rakyat;

3. Rendahnya integritas moral, kredibilitas, profesionalitas dan kesadaran hukum aparat penegak hukum (bakim, jaksa, polisi, advokat) dalam menegakkan hukum.

4. Minimnya sarana dan prasarana serta fasilitas yang mendukung kelancaran proses penegakan hukum;

5. Tingkat kesadaran dan budaya hukum masyarakat yang masih rendah serta kurang respek terhadap hukum;

6. Paradigma penegakan hukum masih positivis-legalitas yang lebih mengutamakan tercapainya keadilan formal (formal justice) daripada keadilan substansial (substansial justice);

7. Kebijakan (policy) yang diambil oleh para pihak terkait (stakeholders) dalam mengatasi persoalan penegakan hukum masih bersifat parsial, tambal sulam, tidak komprehensif dan tersistematis;

Mencermati berbagai problem yang menghambat proses penegakan hukum sebagaimana diuraikan di atas. Langkah dan strategi yang sangat mendesak (urgent) untuk dilakukan saat ini sebagai solusi terhadap persoalan tersebut ialah melakukan pembenahan dan penataan terhadap sistem hukum yang ada. Menurut Lawrence Meir Friedman di dalam suatu sistem hukum terdapat

\footnotetext{
19 Baca selengkapnya dalam Soerjono Soekanto, FaktorFaktor yang Mempengarubi Penegakan Hukum di Indonesia, Cet. V, Jakarta, Raja Grafindo Persada, 2004, hlm. 1168.
}

tiga unsur ${ }^{20}$ (three elements of legal system) yaitu, struktur (structure), subtansi (substance) dan kultur hukum (legal culture). Dalam konteks Indonesia, reformasi terhadap ketiga unsur sistem hukum yang dikemukakan oleh Friedman tersebut sangat mutlak untuk dilakukan.

\section{Harmonisasi Konflik Antar Lembaga atau Institusi Penegak Hukum Dalam Sistem Negara Hukum Indonesia}

Harmonisasi dalam KBBI diartikan sebagai upaya mencari keselarasan ${ }^{21}$, dalam websters new twentieth century dictionary, harmonization diartikan the art of harmonizing. Kata harmonisasi sendiri berasal dari kata harmoni yang dalam bahasa Indonesia berarti pernyataan rasa, aksi, gagasan dan minat: keselarasan, keserasian. Harmonisasi dalam bahasa Inggris disebut harmonize, dalam bahasa Perancis disebut dengan harmonie, dan dalam bahasa Yunani disebut harmonia. Harmonize menurut websters new twentieth century dictionary adalah:

"a fitting together, agreement, to exist in peace and friendship as individuals or families (1) combination of parts into an orderly orproportionate whole, (2) agreement in feeling, idea, action, interest etc. ${ }^{22 "}$.

Dari rumusan kata harmonisasi diatas maka harmonisasi antar lembaga atau institusi penegak hukum adalah upaya untuk menselaraskan ide, gagasan, cita-cita dan aksi dalam penegakan hukum yang tanpa pandang bulu, tanpa melihat siapa orangnya, tetap mengacu pada asas equality before the law agar menjadi proporsional dan menjaga profesionalitas demi kepentingan bersama atau masyarakat.

Dalam hal cakupan harmonisasi hukum, L.M Gandhi yang mengutip buku Tussen Eenheid en Verscheidenheid: Opstellen Over Harmonisatie Instaat en Bestuurecht (1998) mengatakan bahwa harmonisasi dalam hukum adalah mencakup penyesuaian peraturan perundang-undangan, keputusan pemerintah, keputusan hakim, sistem hukum dan asas-asas hukum dengan tujuan peningkatan kesatuan hukum, kepastian hukum, keadilan (jus-

${ }^{20}$ Lawrence Meir Friedman, Law and Society: An Introducton, Englewwod Cliffs, Prentice Hall, 1977 dalam Soerjono Soekanto, Ibid.

${ }^{21}$ Kamus Besar Bahasa Indonesia Online, www. Kamusbahasaindonesia.org, diunduh 28 Januari 2015.

22 Jean L. McKechine, Websters New Twentieth Century Dictionary Unabridged (Second Edition: 1983), hlm. 828. 
tice, gerechtigbeid) dan kesebandingan (equit, bilijkeid), kegunaan dan kejelasan hukum, tanpa mengaburkan dan mengorbankan pluralism hukum kalau memang dibutuhkan. ${ }^{23}$ Sementara menurut Badan Pembinaan Hukum Nasional dalam buku yang disusun oleh Moh. Hasan Wargakusumah dan kawan-kawan, harmonisasi hukum adalah kegiatan ilmiah untuk menuju proses pengharmonisasian tertulis yang mengacu baik pada nilai-nilai filosofis, sosiologis, ekonomis maupun yuridis ${ }^{24}$.

Penegakan hukum ditujukan guna untuk meningkatkan ketertiban dan kepastian hukum dalam masyarakat. Hal ini dilakukan antara lain dengan menertibkan fungsi, tugas, dan wewenang lembaga-lembaga yang bertugas menegakkan hukum menurut proporsi ruang lingkup masingmasing, serta didasarkan atas sistem kerjasama yang baik dan mendukung tujuan yang hendak dicapai.

Tingkat perkembangan masyarakat tempat hukum diberlakukan mempengaruhi pola penegakan hukum, karena dalam masyarakat modern yang bersifat rasional dan memiliki tingkat spesialisasi dan differensiasi yang tinggi pengorganisasian penegak hukumnya juga semakin kompleks dan birokratis.

Pembicaraan penegakan hukum dalam kenyatan sehari-hari tampak bahwa hubungan antara penegakan hukum dan struktur masyarakat memberikan pengaruh yang sangat kuat terhadap cara-cara penegakan hukum suatu negara. ${ }^{25}$ Indonesia sebagai negara modern tampak dari ciricirinya sebagai berikut :

1. Adanya UUD dalam bentuk tertulis;

2. Hukum itu berlaku untuk wilayah negara;

3. Hukum merupakan sarana yang dipakai secara sadar untuk mewujudkan keputusankeputusan politik masyarakatnya;

4. Menurut Max Weber cara penegakan hukum pada suatu masa berbeda dengan masa yang sebelumnya yang tentunya tidak terlepas dari

${ }^{23}$ Ten Berge dan De Waard, seperti dikutip L.M Gandhi, "Harmonisasi Hukum Menuju Hukum Responsif”, Pidato Pengukuhan Jabatan Guru Besar Tetap pada Fakultas Hukum Universitas Indonesia (Jakarta 14 Oktober 1995).

${ }^{24}$ Moh. Hasan Wargakusumah dkk, "Perumusan Harmonisasi Hukum Tentang Metodologi Harmonisasi Hukum”, Badan Pembinaan Hukum Nasional, Departemen Kehakiman dan Hak Asasi Manusia RI (Jakarta, 1996).

25 Satjipto Rahardjo, Masalah Penegakan Hukum, Bandung: Sinar Baru, 1983, hlm. 8. dominasi yang disebabkan karena keadaan masyarakatnya yang berbeda, dimana tatanan kehidupan masyarakatnya menurut Hart dalam Satjipto Rahardjo didasarkan Secondary Rules Oblogation di mana masyarakatnya mempunyai kehidupan yang terbuka, luas, dan kompleks seperti saat ini maka terdapat diferensiasi dan institusionalisasi pekerjaan hukum berupa :

\section{a. Rules of Recognition; \\ b. Rules of Change; \\ c. Rules of Adjudication;}

Salah satu yang paling menonjol yang dirasakan di Indonesia saat ini adalah sifat birokrasinya penegakan hukum yang sesuai dengan kewenangan masing-masing institusi atau lembaga hukum yang bertugas menegakan hukum sesuai dengan kewenangan yang telah diberikan oleh Undang-Undang. Harmonisasi antar lembaga atau institusi penegak hukum sangatlah berperan penting di dalam upaya penegakan itu sendiri, terlebih lagi jika kita berbicara tentang upaya-upaya pemberantasan korupsi di Indonesia. Masalah korupsi adalah masalah pidana atau kriminalitas yang jelas melawan hukum. Masalah pidana maupun krimina-litas di negara ini telah memiliki lembaga penegak hukum yaitu Polri dan Kejaksaan. Ketika KPK dilahirkan, maka secara implisit memang ada sebuah ketidakpercayaan lagi terhadap lembaga negara tersebut untuk melenyapkan korupsi di negara ini.

Walaupun begitu, ketiga lembaga tersebut sudah sewajarnya berjalan beriringan dan saling bekerja sama untuk memberantas korupsi. Sayangnya dalam perjalanannya, ketiga lembaga atau institusi penegak hukum ini acapkali terjadi pro dan kontra dalam penanganan perkara yang berkaitan dengan kewenangannya masing-masing terlebih lagi akan terlihat sangat mencolok ketika perkara-perkara ini melibatkan petinggi atau pimpinan dari dua lembaga atau institusi ini baik dari Polri maupun KPK, sehingga akan memunculkan suatu polemik di dalam masyarakat yang akan dapat membentuk suatu opini publik tentang citra penegakan hukum di Indonesia.

Ketidakharmonisan dua lembaga atau insititusi penegak hukum ini sekarang sedang ramai diberitakan kembali, konflik yang terjadi dimulai dari penetapan tersangka oleh KPK kepada calon tunggal Kapolri yang diajukan oleh Presiden yaitu 
Komisaris Jenderal BG (nama samaran atau alias) ketika masih menjabat sebagai Kepala Biro Pembinaan Karir Deputi SSDM Mabes Polri tahun 2004-2006. Banyak pertanyaan yang muncul dipublik mengapa KPK baru menetapkan Komisaris Jenderal BG sebagai tersangka ketika dirinya dicalonkan menjadi Kapolri. Penetapan Komisaris Jenderal BG sebagai tersangka itu sendiri karena terkait dengan adanya dugaan kasus transaksi keuangan yang tidak wajar sekitar tahun 2006 di rekening Komjen BG atau rekening gendut yang akan mengarah kepada kasus korupsi (gratifikasi) dan sebagaimana yang telah disangkakan kepada Komjen BG adalah telah melanggar Pasal 12 huruf a atau b, Pasal 5 ayat (2), Pasal 11 atau Pasal 12B UU 31 Tahun 1999 Tentang Tindak Pidana Korupsi Juncto. Pasal 55 ayat 1 ke-1 $\mathrm{KUHP}^{26}$. Pengertian gratifikasi sendiri terdapat pada Penjelasan Pasal 12B Ayat (1) Undang-Undang Nomor 31 Tahun 1999 Juncto. Undang-Undang Nomor 20 Tahun 2001, bahwa:

"Yang dimaksud dengan "gratifikasi" dalam ayat ini adalah pemberian dalam arti luas, yakni meliputi pemberian uang, barang, rabat (discount), komisi tanpa bunga, tiket perjalanan, fasilitas lainnya. Gratifikeasi tersebut baik yang diterima di dalam negeri maupun luar negeri dan yang dilakukan dengan menggunakan sarana elektronik atau tanpa sarana elektronik.".

Meskipun Komjen BG telah ditetapkan sebagai tersangka, DPR tetap melanjutkan Fit and Proper Test yang dilakukan guna memberikan penilaian kelayakan Komjen BG sebagai calon Kapolri yang hasilnya akan disampaikan kepada Presiden sebagaimana yang ditegaskan dalam Pasal 11 ayat (1) Undang-Undang No.2 Tahun 2002 Tentang Kepolisian Negara Republik Indonesia bahwa "Kapolri diangkeat dan diberhentikan oleh Presiden dengan persetujuan Dewan Perwakilan Rakyat".

Sepekan kemudian setelah KPK menetapkan Komjen BG sebagai tersangka secara mengejutkan terjadi penangkapan dan penetapan tersangka kepada salah satu pimpinan KPK yaitu BW (nama samaran atau alias), polisi menyatakan penangkapan BW terkait dengan kasus sengketa Pemilukada Kotawaringin Barat tahun 2010 yaitu Pemilihan Bupati Pangkalan Bun, yang pada saat itu BW sebagai kuasa hukum dari Bupati Terpilih Pangkalan Bun Kotawaringin Barat atas nama Ujang Iskandar.

\footnotetext{
${ }^{26}$ Telah diposting pada hari Selasa, 13 Januari 2015, 16:23 WIB, http/www.m.news.viva.co.id
}

BW diduga telah melakukan tindak pidana mengarahkan saksi untuk memberikan keterangan palsu dihadapan persidangan yang pada saat itu sedang diperiksa dan diadili di Mahkamah Konstitusi. Sekali lagi terjadi kontradiktif dengan fakta yang ada bahwasanya Mahkamah Konstitusi sendiri tidak pernah menyatakan bahwa saksi yang dihadirkan oleh pihak pemohon adalah saksi palsu, sehingga dengan adanya penangkapan dan penetapan status tersangka kepada BW menuai pro dan kontra dikalangan para praktisi hukum, akademisi, politisi, kepolisian, maupun masyarakat luas. Menurut ketentuan Bab IX tentang sumpah palsu dan keterangan palsu Pasal 242 ayat (1) KUHP menyebutkan bahwa:

"Barangsiapa dalam hal di mana Undang-Undang menentukan supaya memberi keterangan di atas sumpah, atau mengadakan akibat bukum kepada keterangan yang demikian, dengan sengaja memberi keterangan palsu di atas sumpah, baik dengan lisan atau tulisan, olehnya sendiri maupun oleh kuasanya yang khusus ditunjuk untuk itu, diancam dengan pidana penjara paling lama tujub tabun", kemudian pada ayat (2) disebutkan "Iika keterangan palsu di atas sumpah, diberikan dalam perkara pidana dan merugikan terdakwa atau tersangka, yang bersalah dikenakan pidana penjara paling lama sembilan tabun", dan pada ayat (3) disebutkan "Disamakan dengan sumpah adalah janji atau penguatan, yang diharuskan menurut aturan-aturan umum atau yang menjadi pengganti sumpab".

Menurut ketentuan Bab V tentang penyertaan dalam melakukan perbuatan pidana : Pelaku yang menyuruh lakukan, yang turut serta melakukan dan penganjur Pasal 55 ayat (1) KUHP ditegaskan bahwa:

"Dipidana sebagai pembuat (dader) sesuatu perbuatan pidana:

ke-1. Mereka yang melakukan, yang menyuruh lakukan dan yang turut serta melakukan perbuatan;

ke-2. Mereka yang dengan memberi atau menjanjikan sesuatu, dengan menyalahgunakan kekuasaan atau martabat, dengan kekerasan, ancaman atau penyesatan, atau dengan memberi kesempatan, sarana atau keterangan, sengaja menganjurkan orang lain supaya melakukan perbuatan;"

Kemudian pada ayat (2) ditegaskan pula bahwa:

"Terbadap penganjur hanya perbuatan yang sengaja dianjurkan sajalah yang diperbitungkan, beserta akibatakibatnya". 
Para Advokat yang tergabung didalam Asosiasi Advokat Mahkamah Konstitusi merasa keberatan dengan adanya penangkapan dan penetapan tersangka oleh Polri kepada BW, karena mereka menganggap bahwa profesi Advokat adalah profesi yang terhormat (Officium Nobille) dan Advokat adalah berkedudukan yang sama yaitu sebagai penegak hukum (bakim, polisi, jaksa), sebagaimana yang ditegaskan di dalam Bagian Ketiga tentang Status Pasal 5 ayat (1) UndangUndang No.18 Tahun 2003 Tentang Advokat yang menyatakan bahwa "Advokat berstatus sebagai penegak. bukum, bebas, dan mandiri yang dijamin oleb bukum dan peraturan perundang-undangan".

Selain itu pula Advokat mempunyai hak imunitas (kebal hukum) didalam menjalankan profesinya sebagaimana yang ditegaskan pula didalam Pasal 16 Undang-Undang No.18 Tahun 2003 tentang Advokat yang menyatakan bahwa "Advokat tidak dapat dituntut baik secara perdata maupun pidana dalam menjalankan tugas profesinya dengan itikad baik untuk kepentingan pembelaan Klien dalam sidang pengadilan".

\section{Kesimpulan}

Penelitian ini menyimpulkan bahwa terdapat pengakuan normatif dan empirik akan prinsip supremasi hukum, yaitu bahwa semua masalah diselesaikan dengan hukum sebagai pedoman tertinggi. Dalam perspektif supremasi hukum (supremacy of law), pada hakikatnya pemimpin tertinggi negara yang sesungguhnya bukanlah manusia, tetapi konstitusi yang mencerminkan hukum yang tertinggi. Pengakuan normatif mengenai supremasi hukum adalah pengakuan yang tercermin dalam perumusan hukum dan/atau konstitusi, sedangkan pengakuan empirik adalah pengakuan yang tercermin dalam perilaku sebagian terbesar masyarakatnya bahwa hukum itu memang "supreme".

Secara normatif baik dalam Undang-Undang Dasar Negara Republik Indonesia Tahun 1945, maupun dalam Undang-Undang Nomor 39 Tahun 1999 Tentang Hak Asasi Manusia, prinsip equality treatment before the law telah dimuat secara komprehensif, sebagai hak asasi yang harus dihormati, dijamin, dilindungi dan dipenuhi oleh negara. Persamaan dihadapan hukum (equality before the law) diartikan bahwa yang sama akan diperlakukan yang sama, dan yang tidak sama akan diperlakukan tidak sama. Pembedaan perlakuan atas dasar agama, ras, etnik, kelompok, golongan, status sosial, status ekonomi, jenis kelamin, bahasa, keyakinan politik, dilarang dan setiap orang berhak mendapatkan perlindungan atas perlakuan yang diskriminatif.

Disharmonisasi antar lembaga atau institusi penegak hukum yang sekarang sedang marak terjadi, seharusnya dapat segera diselesaikan dengan mendasarkan kepada peraturan perundangundangan yang ada. Proses penegakan hukum adalah bagian dari sistem Negara Hukum di Indonesia sebagaimana yang telah dinyatakan secara tegas di dalam Pasal 1 ayat (3) UUD 1945 NRI bahwa: "Negara Indonesia adalah Negara Hukum", untuk itu tidak ada satu apapun yang menjadi alasan bagi lembaga atau institusi penegak hukum melakukan tebang pilih dalam penanganan perkara. Tidak boleh ada intervensi apapun dan dari siapapun didalam upaya penegakan hukum di Indonesia, terlebih lagi jika ada kepentingankepentingan politik yang berusaha mengintervensi upaya-upaya penegakan hukum di Indonesia.

Sebagai penutup ijinkan peneliti mengutip kata-kata yang diucapkan oleh Ferdinand I (15031564) Raja Hungaria dan Bohemia dari 1558 sampai dengan 1564, yaitu :

"Fiat Justitia et Pereat Mundus, yang artinya Hendaklah Keadilan Ditegakkan, Walaupun Dunia Harus Binasa".

\section{Daftar Pustaka}

Azhary, 1995, Negara Hukum Indonesia - Analisis Yuridis Normatif Tentang Unsur-unsurnya, Jakarta, Cet. Pertama UI Press.

Bagir Manan, 1993, Kekuasaan Kehakiman di Indonesia Sejak Kembali ke UUD 1945, dalam Sri Soemantri Martosoewignjo dan Bintan R. Saragih, Ketatanegaraan Indonesia Dalam Kebidupan Politik Indonesia - 30 Tabun Kembali ke Undang-Undang Dasar 1945, Jakarta, Pustaka Sinar Harapan

Burns H. Weston, 1993, Hak-Hak Manusia, dalam Hak-Hak Asasi Manusia dalam Masyarakat Dunia, Isu dan Tindakan, T. Mulya Lubis (Penyunting), diterjemahkan oleh A. Setiawan Abadi, Yayasan Obor Indonesia

J. G. Merrills, 1993, The Development of International Law By The European Court of Human Rights, Manchester University Press 
Jean L. McKechine, 1983, Websters New Twentieth Century Dictionary Unabridged, Second Edition

Lawrence Meir Friedman, 1997, Law and Society: An Introducton, Englewwod Cliffs, Prentice Hall, dalam Soerjono Soekanto

Moh. Hasan Wargakusumah dkk, 1996, "Perumusan Harmonisasi Hukum Tentang Metodologi Harmonisasi Hukum", Badan Pembinaan Hukum Nasional, Departemen Kehakiman dan Hak Asasi Manusia RI, Jakarta

Peter Westen, The Empty Idea Of Equality, 95 Harvard Law Review 537

Ralph C. Chandler et. al., 1987, The Constitutional Law Dictionary, Volume 2, ABC-CLIO, Santa Barbara, California, Oxford England

Satjipto Rahardjo, 1983, Masalab Penegakan Hukum, Bandung : Sinar Baru

Soerjono Soekanto, 1983, Faktor-faktor Yang Mempengarubi Penegakean Hukum, Jakarta, Cet. Pertama CV. Rajawali

Sri Soemantri Martisoewignjo,1992, Asas Negara Hukum dan Perwujudannya dalam Sistem Hukum Nasional, dalam M.B. Muqoddas dkk, Politik Pembangunan Hukum Nasional, Yogyakarta, UII Press

Ten Berge dan De Waard, 1995, seperti dikutip L.M Gandhi, "Harmonisasi Hukum Menuju Hukum Responsif", Pidato Pengukuhan Jabatan Guru Besar Tetap pada Fakultas Hukum Universitas Indonesia (Jakarta 14 Oktober 1995)

W. Friedman, 1994, Teori Dan Filsafat Hukum, Hukum dan Masalah-Masalah Kontemporer, diterjemahkan dari Legal Theory, oleh Muhammad Arifin, Penerbit PT. Raja Grafindo

Yusril Ihza Mahendra, Dekrit Presiden 5 Juli 1959 dan Implikasinya terhadap Perumusan Politik. Hukum Nasional, makalah disampaikan pada seminar sehari Menyongsong Hari Kemerdekaan RI ke 50, tanggal 5 Agustus 1945 yang diselenggarakan oleh ICMI Korwil DKI Jakarta

\section{Undang-Undang}

Undang-Undang Dasar Negara Republik Indonesia 1945

Undang-Undang No.8 Tahun 1981 Tentang Hukum Acara Pidana

Undang-Undang No. 39 Tahun 1999 Tentang Hak Asasi Manusia

Undang-Undang No.31 Tahun 1999 Jo. UndangUndang No.20 Tahun 2001 Tentang Pemberantasan Tindak Pidana Korupsi

Undang-Undang No.30 Tahun 2002 Tentang Komisi Pemberantasan Tindak Pidana Korupsi

Undang-Undang No.2 Tahun 2002 Tentang Kepolisian Negara Republik Indonesia

Undang-Undang No.18 Tahun 2003 Tentang Advokat

Kitab Undang-Undang Hukum Pidana

Undang-Undang No.48 Tahun 2009 Tentang Kekuasaan Kehakiman

\section{Kamus Hukum}

Pusat Pembinaan dan Pengembangan Bahasa, 1996, Kamus Besar Bahasa Indonesia, Edisi Kedua, Cet. Kedelapan, Jakarta, Balai Pustaka

Kamus Besar Bahasa Indonesia online, www. Kamusbahasaindonesia.org, diunduh 28 Januari 2015

\section{Artikel Media Massa}

Telah diposting pada hari Selasa, 13 Januari 2015, 16:23 WIB, http/www.m.news.viva.co.id 